1,25-dihydroxycholecalciferol and parathyroid hormone like factors. ${ }^{3}$ Hypercalcaemia in haematological malignancies is a well described complication, and humoral factors involved in the pathogenesis are still being investigated, but this presentation is uncommon in this rare subspecialty of Hodgkin's disease. Reports have described hypercalcaemia with no evidence of skeletal metastases or bone marrow abnormalities in Hodgkin's disease, ${ }^{45}$ and established evidence has shown that 1,25-dihydroxycholecalciferol is the factor produced by the tumour. ${ }^{6-8}$ However, Jacobsen et al suggest that 1,25-dihydroxycholecalciferol cannot be the sole humoral mediator of hypercalcaemia in Hodgkin's disease as shown by in vitro bone resorption studies. ${ }^{9}$ Bone resorption activity in a tumour conditioned medium greatly exceeded that attributed to the measured 1,25-dihydroxycholecalciferol; the resorption shown by the medium was dependent on enhanced cycloxygenase activity that was probably produced by a co-factor.

The identification of PTHRP has helped to explain some of the features in hypercalcaemia of malignancy, as it has been implicated as a possible contributing factor in this condition. ${ }^{111}$ The development of different region specific radioimmunoassays and immunohistochemical staining methods on the tumour tissue have made this possible. ${ }^{1212}$ Recent immunohistochemical studies in adult $\mathrm{T}$ cell leukaemia/lymphoma (ATLL) have shown the presence of PTHRP in the tumour tissue. ${ }^{13}$ Immunohistochemical staining for PTHRP was performed on formalin fixed, paraffin wax embedded sections of the tumour tissue and control tissue sections, as described previ- ously, ${ }^{2}$ but as shown in our patient, we did not detect PTHRP in the serum nor in the tumour tissue. We conclusively state that PTHRP was not one of the humoral factors associated with the episode of hypercalcaemia in this case of Hodgkin's disease.

1 Ratcliffe WA, Norbury S, Heath DA, Ratcliffe JG. Development and validation of an immunoradiometric assay of parathyrin-related protein in unextracted plasma. Clin Chem 1991;35:678-85.

2 Bundred NJ, Ratcliffe WA, Walker RA, Coley S, Morrison JM, Ratcliffe JG. Parathyroid hormone related protein and hypercalcaemia in breast cancer. BMY 1991;303:1506-9.

3 Ralston SH. The pathogenesis of humoral hypercalcaemia of malignancy. Lancet 1987;ii:1443-6.

4 Ellis RD, Beck PR, Mondal BK. Hodgkin's disease presenting with hypercalcaemia. $\mathcal{F}$ Clin Pathol 1989;42:1228.

5 Mayne KM, Bunch C. Hodgkin's disease presenting with hypercalcaemia. f Clin Pathol 1989;42:219.

6 Needle MA, Chandra B. Hypercalcaemia, Hodgkin's disease, and calcitriol. Ann Intern Med 1984;100:916.

7 Rieke JW, Donaldson SS, Horning SJ. Hypercalcaemia and vitamin D metabolism in Hodgkin's disease. Cancer vitamin D metabc

8 Mercier RJ, Thompson JM, Harman GS, Messerschmidt GL. Recurrent hypercalcaemia and elevated 1, 25-dihydroxycholecalciferol levels in Hodgkin's disease. $\mathrm{Am} \mathfrak{J}$ Med 1988;84:165-8.

9 Jacobson JO, Bringhurst FR, Harris NL, Weitzman SA, Aisenberg AC. Humoral hypercalcaemia in Hodgkin's disease. Cancer 1989;63:917-23.

10 Ralston SH, Danks J, Hayman J, Fraser WD, Stewart CS Martin TJ. Parathyroid hormone related protein of malignancy: Immunohistochemical and biochemical

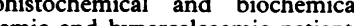
with cancer. 7 Clin Pathol 1991;44:472-6.

11 Heath DA, Senior PV, Varley JM, Beck F. Parathyroid hormone related protein in tumours associated with hypercalcaemia. Lancet 1990;335:66-9.

12 Danks JA, Ebeling PR, Hayman J, et al. Parathyroid hormone related protein of cancer; immunohistochemical ocalization in cancers and in normal skin. $\mathcal{F}$ Bone Min Res 1989;4:273-7.

13 Moseley JM, Danks JA, Grill V, Lister TA, Horton MA. Immunocytochemical demonstration of PTHrP protein in neoplastic tissue of HTLV-1 positive human adult T cell leukaemia/lymphoma: implications for the mechanism of hypercalcaemia. Br $\mathcal{F}$ Cancer 1991;64:745-8.

\title{
Increase in severity of graft versus host disease by cytomegalovirus
}

\author{
A L McCarthy, J S Malik Peiris, C E Taylor, M A Green, L Sviland, A D J Pearson, \\ A J Malcolm
}

Department of
Pathology, Royal
Victoria Infirmary,
Newcastle upon Tyne
NE1 4LP
A L McCarthy
M A Green
L Sviland
A J Malcolm
Department of
Virology
J S Malik Peiris
C E Taylor
Department of Child
Health
A D J Pearson
Correspondence to:
Dr A L McCarthy
Accepted for publication
30 October 1991

Department of

Victoria Infirmary,

Newcastle upon Tyne

A L McCarthy

A J Malcolm

Department of

Virology

C E Taylor

Department of Child

Correspondence to:

Dr A L McCarthy

30 October 1991

\begin{abstract}
An allogeneic transplant recipient developed severe graft versus host disease (GvHD) 48 days after transplantation that was concomitant with a cytomegalovirus (CMV) viraemia, from which she subsequently died. CMV infection was detected in blood by the polymerase chain reaction and later in tissue by immunohistochemical techniques. CMV should be considered in patients in whom GvHD does not respond to appropriate treatment, and this case suggests that herpes viruses may increase the severity of GvHD by synergistically enhancing the graft versus host reaction.
\end{abstract}

Graft versus host disease (GvHD) is a major complication of bone marrow transplantation (BMT) and continues to be the main factor that currently limits allogeneic BMT. ${ }^{1}$ An increasing number of studies over the past decade have reported an association between herpes viruses and GvHD and, in particular, the frequent clinical association of cytomegalovirus (CMV) with GvHD. ${ }^{2-5}$ Attempts to link herpes virus infection and GvHD in a causal relationship have so far mainly been based on serological studies. No previous study, as far as we know, has examined the target organs in GvHD for viral infection.

The organs affected in GvHD are primarily the skin, gut, and liver. We have been pro- 
Virological investigations

\begin{tabular}{|c|c|c|c|c|c|c|}
\hline $\begin{array}{l}\text { Days after } \\
B M T\end{array}$ & Specimen & $\begin{array}{l}\text { CMV } \\
\text { culture }\end{array}$ & $\begin{array}{l}C M V \\
P C R\end{array}$ & $\begin{array}{l}\text { Clinical condition/ } \\
\text { immunohistochemistry }\end{array}$ & $\begin{array}{l}\text { Serole } \\
\text { CFT }\end{array}$ & \\
\hline-7 & Anticoagulated blood & - & \multirow{2}{*}{\multicolumn{2}{|c|}{ Transplanted }} & & \\
\hline 0 & $\leftarrow$ & & & & & $\rightarrow$ \\
\hline 13 & Serum & & & & $<20$ & negative \\
\hline $\begin{array}{l}14 \\
15\end{array}$ & $\begin{array}{l}\text { Urine, throat swab } \\
\text { Serum }\end{array}$ & -- & & & & Negative \\
\hline $\begin{array}{l}20 \\
21\end{array}$ & $\begin{array}{l}\text { Urine, throat swab } \\
\text { Serum }\end{array}$ & -- & & Mild GvHD & & Negative \\
\hline 29 & Urine, throat swab & -- & & & & \\
\hline $\begin{array}{l}48 \\
49\end{array}$ & $\begin{array}{l}\text { Blood, throat swab, serum } \\
\text { Urine }\end{array}$ & + & ++ & Moderately severe GvHD & $<20$ & negative \\
\hline 50 & Rectal biopsy, skin biopsy & -- & & $\begin{array}{l}\text { CMV detected } \\
\text { immunohistochemically in } \\
\text { rectum }\end{array}$ & & \\
\hline $\begin{array}{l}51 \\
54\end{array}$ & $\begin{array}{l}\text { Urine, throat swab } \\
\text { Urine }\end{array}$ & $\begin{array}{l}-- \\
-\end{array}$ & & & & \\
\hline 56 & Blood & + & ++ & & & \\
\hline 61 & Blood & - & ++ & & & \\
\hline 70 & Blood & - & + & & & \\
\hline 74 & Throatswab & + & & & & \\
\hline 78 & $\leftarrow$ & & & & & $\rightarrow$ \\
\hline 78 & Lung, liver at necropsy & ++ & & $\begin{array}{l}\text { CMV detected } \\
\text { immunohistochemically }\end{array}$ & & \\
\hline
\end{tabular}

*complement fixation titre.

spectively studying skin and rectal biopsy material from bone marrow transplant recipients in Newcastle upon Tyne to investigate the association between herpes viruses and GvHD using the polymerase chain reaction, and in situ hybridisation, to detect viral DNA, in addition to standard histological and immunohistochemical techniques.

It has been postulated that exposure to viral antigens due to reactivation, reinfection, or de novo infection with herpes viruses can initiate or exacerbate GvHD. A mechanism for this may be that in GvHD viral antigen or virally induced changes in the expression of histocompatibility antigens on host cells may serve as a target for donor immune surveillance. We report a case that is consistent with this hypothesis.

\section{Case report}

A 44 year old woman with chronic myeloid leukaemia in chronic phase who was seropositive for CMV before transplantation received an allogeneic bone marrow transplant from her HLA identical brother, who was seronegative for CMV. Skin and rectal biopsy specimens were normal before the transplantation. She was conditioned for the transplantation by total body irradiation and $60 \mathrm{mg} / \mathrm{kg}$ cyclophosphamide daily for two successive days and she was transplanted with filtered irradiated blood product support.

The initial period after the transplantation was uneventful. She developed mild GvHD (grade 1$)^{6} 21$ days after BMT which responded to high dose methylprednisolone. However, 48 days after BMT she developed an extensive skin rash and diarrhoea and her condition began to deteriorate. Biopsy specimens of both skin and rectum taken at this stage showed evidence of more severe GvHD (grade 2). She was treated with high dose methylprednisolone but did not respond to this. Concomitant with this deterioration, peripheral blood taken on day 48 after BMT was positive for CMV by the DEAFF test (seven day culture). Ganciclovir was started on day 55 at a dose of $300 \mathrm{mg}$ twice daily. However, the patient's platelet count fell after two days of treatment, raising the possibility of ganciclovir toxicity. Ganciclovir was discontinued 64 days after BMT. The following day, 65 days after BMT, intravenous anti-CMV immunoglobulin was started at a dose of $18 \mathrm{~g}$ once a day for three days until 67 days after transplantation. By 61 days and 70 days post BMT, peripheral blood had become negative for CMV by the DEAFF test (table).

Her clinical condition worsened and liver function tests continued to become increasingly abnormal, with a steady rise in conjugated bilirubin ( $55 \mu \mathrm{mol} / 1$ at 63 days, 344 at 71 , 1014 at 78 ). Her alkaline phosphatase activity also rose but her alanine amino transferase activity was only marginally raised. There was little to suggest disease in other organ systems, the chest radiograph being persistently normal and clinical examination of the chest indicating no abnormalities. Her liver failure was thought to be due to GvHD; CMV hepatitis was not considered the most likely diagnosis in view of the sharp rise in conjugated bilirubin and only a marginal increase in alanine transferase.

She deteriorated further and died of liver failure 78 days after transplantation. At necropsy, the cause of death was found to be disseminated CMV infection, with immunohistochemical evidence of CMV in the lungs, liver, small intestine, rectum, kidney and spleen.

As part of the research protocol, peripheral blood leucocytes taken on days 48,61 , and 70 after transplantation were analysed for CMV by the polymerase chain reaction (PCR) using primers to the CMV IE gene ${ }^{7}$ and found to be positive for CMV. Peripheral blood leucocytes taken before transplantation were negative for CMV by the PCR.

The rectal biopsy specimen taken on day 50 was also retrospectively analysed as part of the research protocol and was found to be positive for CMV antigen by immunohistochemical techniques using the Dakopatts monoclonal antibody $\mathrm{CCH}_{2}$ (table).

This case report raises several interesting 
points. First, CMV should be considered in patients in whom GvHD does not respond to appropriate treatment. In this case, CMV viraemia was concomitant with the relapse in GvHD and this seems to support the hypothesis that CMV may increase the severity of GvHD by synergistically enhancing the graft versus host reaction. Second, the differentiation of GvHD from CMV is difficult histologically and immunohistochemistry is useful in this regard. Third, in spite of detectable CMV viraemia, repeated urine and throat swab specimens were negative for CMV by culture until the terminal stages of the illness ( 74 days after BMT).

Finally, CMV viraemia was not detectable by culture 56 days after BMT. However, the virus was detectable in the peripheral blood by PCR up to the time of death, and death was caused by disseminated CMV infection. Herman $e t$ al have recently suggested that the PCR may have a role in the early detection of CMV in the period immediately after transplantation before any clinical symptoms of viraemia or GvHD are evident. ${ }^{8}$

Using agarose gel electrophoresis with ethidium bromide staining to detect the amplified PCR product, the technique that we used does not detect CMV DNA in the peripheral blood of healthy seropositive subjects. Furthermore, we have so far studied 22 transplant recipients, 13 of whom were seropositive for CMV before surgery, and have obtained negative PCR results for $\mathrm{CMV}$ at several time intervals after transplantation in 21 patients, all of whom were shown not to have been actively infected with CMV. This preliminary evidence suggests that PCR may be able to differentiate clinically important active CMV infection from subclinical infection. As profound immunosuppression may facilitate the reactivation of latent CMV, the differentiation of active CMV infection by PCR may be important in the management of immunosuppressed patients.

We thank Dr S J Proctor for permission to publish data about his patient.

1 O'Reilly RJ. Allogeneic bone marrow transplantation: Current status and future directions. Blood 1983;62:941-64.
Miller W, Flynn P, McCullough J, et al. Cytomegalovirus infection after bone marrow transplantation: an association with acute graft-versus-host disease. Blood 1986;67:1162-7.

3 Meyers JD, Fluornoy N, Thomas ED. Risk factors for cytomegalovirus infection after human marrow transplantation. F Infect Dis $1986 ; 153: 478-88$.

4 Lonnquist B, Ringdén O, Wahren B, Gahrton G, Lundgren $G$. Cytomegalovirus infection associated with and preceding chronic graft-versus-host disease. Transplantation ing chronic graft

5 Bôstrom L, Ringdén O, Sundberg B, Linde A, Tollemar F, Nilsson B. Pre-transplant herpes virus serology and acute
graft-versus-host disease. Transplantation 1988;46: graft-versus-

6 Sviland L, Pearson ADJ, Eastham EJ, et al. Histological features of skin and rectal biopsy specimens after autologous and allogeneic bone marrow transplantation. $f$ Clin Pathol 1988;41:148-54,

7 Demmler EJ, Burrone CJH, Schimber CW, Ray RA. Detection of cytomegalovirus in urine from newborns by using polymerase chain reaction DNA amplification. $\mathcal{F}$ Infect Dis 1988;158:1177-84.

8 Herman Ė, Steidle M, Vallbracht A, Saal JG, Ehninger G, Muller CA. Early occurrence of human cytomegalovirus infection after bone marrow transplantation by the polymerase chain reaction technique. Blood 1991; 77:1 104-10.
Department of Clinical Chemistry, Royal Hallamshire Hospital, Sheffield S10 2JF ARW Forrest JH Galloway

Department of Histopathology, Rotherham District General Hospital, Rotherham DN Slater

Correspondence to: Dr ARW Forrest Accepted for publication 30 October 1991

\begin{abstract}
Blood cyanide concentrations were measured in samples obtained from a pathologist before and after carrying out a necropsy on the body of a victim of cyanide poisoning. There was no significant increase in his blood cyanide concentration after carrying out the procedure. It is suggested that an important factor in determining the risk to those carrying out necropsies of the bodies of victims of cyanide poisoning is the amount of cyanide remaining in the stomach. There are several ways in which the theoretical risk inherent in carrying out such necropsies could be reduced, such as the use of a full face respirator, or the removal, intact, of the upper gastrointestinal tract to a fume cupboard for examination.
\end{abstract}

It has been suggested that those involved in the post mortem examination of the bodies of those dying of overdoses of cyanide may be at risk of exposure to toxic concentrations of cyanide. ${ }^{1}$ We recently had the opportunity to assess this risk in practice.

A 40 year old industrial chemist was found dead at home. At the scene were copious amounts of vomit and a note stating that he had taken cyanide with the intention of ending his life. A post mortem examination was carried out within 24 hours of the discovery of the body by an experienced pathologist (DNS) in a post mortem suite equipped with down draught ventilation. This ventilation system produces at least 12 changes of air per hour. Both the pathologist and the anatomical pathology technician in attendance wore antisplash : facemasks and "double" surgical masks. The time taken to carry out the necropsy was 35 minutes, the amount of dissection carried out being the minimum necessary to establish the cause of death. Of necessity this included opening the upper gastrointestinal tract for the recovery of gastric 